\title{
Obesity: Perceived Self-Efficacy, Emotional Regulation and Stress
}

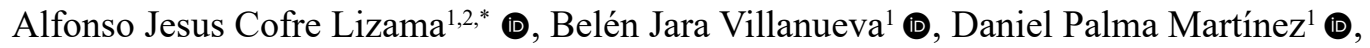 \\ Fredy Cea Leiva ${ }^{3}$ ( \& \& Enrique Riquelme Mella ${ }^{3}$ (D) \\ ${ }^{1}$ Universidad Santo Tomás, Temuco, Chile \\ ${ }^{2}$ Universidad Mayor, Chile \\ ${ }^{3}$ Universidad Católica de Temuco, Temuco, Chile
}

\begin{abstract}
Obesity increases the risk of non-transmissible chronic illnesses decreasing the quality of life and life expectancy. This investigation aims to define a psychological profile for the treatment of the target population evaluating the levels of self-efficacy perceived, difficulty in emotional regulation and stress. Eighty-six adults participated, including 63 women and 23 men who pertained to OBEMOB in Temuco. The results indicate that the level of stress, trust in problem solving skills, as well as ability to solve problems and unexpected situations differs according to the type of obesity $(p<0.05)$. In addition, there is a negative relation between general self-efficacy and difficulty of emotional regulation (rho=-0.419) while stress and BMI demonstrate a positive relation $(\mathrm{rho}=0,380)$.
\end{abstract}

KEYWORDS: types of obesity, self-efficacy perceived, emotional regulation, stress

\section{Obesidad:Autoeficacia Percibida, Regulación Emocional y Estrés}

RESUMEN - La obesidad aumenta el riesgo de enfermedades crónicas no transmisibles, disminuye la expectativa y calidad de vida. Esta investigación busca establecer un perfil psicológico para el tratamiento de la población objetivo, realizar evaluaciones sobre los niveles de autoeficacia percibida, dificultad de la regulación emocional y estrés. Participaron 86 personas adultas, 63 mujeres y 23 hombres pertenecientes a OBEMOB de la ciudad de Temuco. Los resultados señalan que el nivel de estrés, confianza en la resolución de problemas, capacidad de resolución de problemas y resolución de situaciones inesperadas, difiere según el tipo de obesidad $(p<0,05)$. Además, existe una relación negativa entre la autoeficacia general y la dificultad de la regulación emocional $(\mathrm{rho}=-0,419)$ y una relación positiva entre el estrés y el IMC $(\mathrm{rho}=0,380)$.

PALABRAS CLAVES: tipos de obesidad, autoeficacia percibida, regulación emocional, estrés

\section{Obesidade:Autoeficácia Percebida, Regulação Emocional e Estresse}

\begin{abstract}
RESUMO - A obesidade aumenta os riscos de doenças crônicas não-transmissíveis, diminuindo a qualidade e a expectativa de vida. Esta investigação busca delinear o perfil psicológico da população-alvo, avaliando os níveis percebidos de autoeficácia, dificuldade da regulação emocional e estresse. Participaram 86 pessoas adultas, 63 mulheres e 23 homens da cidade de Temuco. Os resultados mostraram que os níveis de estresse, confiança, habilidade para resolução de problemas e para lidar com situações inesperadas variam segundo o tipo de obesidade $(p<0,05)$. Ainda, existe uma relação negativa entre autoeficácia geral e dificuldade de regulação emocional ( $r h o_{=-0.419)}$ e uma relação positiva entre estresse e IMC ( $r h o=0,380)$.
\end{abstract}

PALAVRAS-CHAVES: tipos de obesidade, autoeficácia percebida, regulação emocional, estresse

\footnotetext{
*E-mail: acofrel@gmail.com

- Submetido: 07/01/2017; Revisado: 22/01/2019; Aceito: 16/01/2020.
} 
Overweight and obesity are defined as an unusual increase of fat, mostly in excess, that has serious health damage as consequence (WHO, 2018).

Malnutrition related to overweight is categorized into five types, according to the Body Mass Index (BMI): Increase of weight $>25$, Overweight: between 25-29.9, Class I Obesity: between 30-34,9, Class II Obesity: between 35-39,9 and Class III Obesity: 40 (Ministerio de Salud [MINSAL], 2010). It is estimated that in 2016 more than 1.9 million people over the age of 18 are overweighted and more than 650 million are obese (WHO, 2018). Obesity is one of the most serious and outstanding diseases today (Kushner, 2014). In addition, issues have been noticed concerning high blood pressure, class II diabetes mellitus, heart problems, respiratory and osteoarticular problems, and some types of cancer such as colon, breast, prostate, liver, and esophagus cancer (Sánchez et al., 2014), which are associated with an increased morbidity and mortality rate (Karamouzis et al, 2011).

In Chile, $25.1 \%$ of the population is obese (MINSAL, 2010). The consequences are clear and represent an important economical expense in public health (MINSAL, 2013). Unfortunately, nutritional, pharmacological, and psychological treatments together or apart, get bad results because of low levels of adherence and / or desertion from treatment (González et al, 2007). Even when weight loss programs are effective, keeping lower weight is still difficult (de la Iglesia et al, 2014).

Obesity generates a negative effect in people due to the psychosocial consequences that this disease entails (Wardle et al., 2006) and there are psychological variables that create an important predictor of therapeutic results (Tippens et al, 2014). The recognition of these variables has been essential to improve the efficacy of psychotherapeutic treatments (Lorence, 2008).

\section{Phycological Variables about Obesity and its Treatment}

Emotional Regulation includes the processes that allow monitoring, evaluating and modifying emotional responses, especially their intensity and characteristics over time. That is, emotional regulation is any action designed to modify the intensity or duration of an emotional state (Gúzman et al., 2014).

Those who have a higher ability to regulate their emotions (positive and negative) seem to be less prone to develop psychological disorders (Company et al., 2012). On the other hand, the difficulty to regulate emotions is associated with a higher effect in the anxious and depressive spectrum (Guzmán-González et al., 2014). According to Silva, (2008), obese people have difficulty to get in touch with their emotions, which causes complications in their recognition and regulation, confusing emotions with hunger, leading them to compulsively eat (Goleman, 1999). This way, their psychic mechanisms about emotional self-regulation show that they are not able to deal with situations normally, and they use food intake as a support in emotionally complex situations (Cordella, 2008).

People with high levels of emotional regulation have greater life satisfaction, and demonstrate more happiness and less negative mood states (Limonero et al., 2012). It has been said that the regulation of emotions can be an influential variable in the ability to solve problems and stress, because people with higher emotional management skills could notice stressors as less threatening (Souto, 2013).

Stress is a complex process, in which the individual responds to strong environmental demands or situations (stressor), with a specific pattern of physiological, behavioral, cognitive and emotional responses or a combination of those (García-Rivera et al., 2013).

Stress is understood according to the importance of the stressor and to the extent to which the event can be controlled by the person, that is, what kind of skill the person has to respond in a stressful context, and the effort their body has to put on to adapt to the changes experienced (Durán, 2009). Low levels of adaptation cause changes in health, leading to the emergence of new diseases or worsening of ones that existed previously, such as gastric ulcers, irritable colon, headaches, depression, sleep disorders, among others (Hernández et al., 2009). Research confirms the relationship between stress and motivation to eat (Groesz, et al, 2011). On the other hand, Elder et al. (2011) relate stress with weight changes, emphasizing the negative bidirectional relationship between stress and weight loss, so that stress has been classified as cause and consequence of obesity (Villaseñor et al., 2006).

Stress regulation learning in the early years of life relates eating to being calm, the food intake works as an inadequate stress regulator that creates response patterns that leads the organism to improperly assimilate emotional information, being unable to process their contents, mistaking them for feelings of anxiety that patients solve by eating (Cordella $\&$ Moore, 2015).

Bandura et al. (2003) define self-efficacy as the beliefs people have about their abilities to control the events that affect their lives. Self-efficacy beliefs will determine how people get motivated, feel, think, and behave. An important aspect to understand the self-efficacy concept is considering the difference between having the necessary skills to do something, and feeling confident enough to answer effectively to situations demand or threats (Bandura et al., 2003). People with high levels of self-efficacy will be able to face greater challenges, while people with low levels of self-efficacy will have less commitment to goals and easily abandon them (Hayden \& Peterson 2014). There are several empirical findings that demonstrate that self-efficacy is an 
influencing factor in exercise habits, proving that people with greater self-efficacy are more powerful in complying with a physical activity routine, committing themselves to perform a greater amount of regular physical activity in relation to people with low self-efficacy (Olivarí \& Urra, 2007).

Results have shown that self-efficacy is clearly related to the number of dropouts in treatments to modify the excessive food intake, to the number of attempts to lose weight, to the maintenance of therapeutic gains, and to the weight stability over long periods of time (Tippens et al., 2014). Lugli's study (2011) found that obese people who attend a weight loss treatment show moderate levels of self-efficacy, since they perceive that they are able to comply with the required physical exercise, otherwise they would not be involved in any type of treatment. The perception of self-efficacy as a mediating mechanism is important to the success of weight reduction treatments.

\section{METHOD}

\section{Participants}

Eighty-six people participated, including 63 women (73.3\%) and 23 men (26.7\%) from the morbid obesity group (OBEMOB) in Temuco city. Participants were adults aged between 18 and 65 years old $(\mathrm{M}=41$; DT $=13)$ who have some type of obesity (I, II or III), and take part in the group. The participation in the research was voluntary, a statement of consent was signed, protecting the professional nature of the research. In fact, a copy was given to all the members. Also, the reliability and anonymity about the answers collected were guaranteed. Participants were informed and made aware of the importance and objectives of the research.

\section{Instruments}

\section{Difficulties in Emotion Regulation Scale (DERS-S)}

It is a self-report questionnaire with 25 items, which are rated using a 5-point Likert scale ranging from one (almost never) to five (almost always), where higher scores mean biggest difficulties. It is made up of five factors: emotional lack of control (ELC), daily interference (DI), emotional neglect (EN), emotional confusion (EC) and emotional rejection (ER). The reliability rate was .91 . This instrument was validated in Chile by Guzmán-González et al. in 2014.

\section{Global Stress Perception Scale (GSPS)}

This instrument measures the individual's answers to events or situations called stressors. It is a self-report questionnaire that has 14 items and is assessed using a Likert-type scale, from zero (never) to four (almost always). This questionnaire has three subscales: Confidence in Solving Problems (CSP), Problem Solving Capacity (PSC) and Resolution of Unexpected Situations (RUS). This instrument was adapted to a Chilean population by Tapia et al. (2007), who obtained a Cronbach's alpha of 0.79 . In our population, it obtained a Cronbach's alpha of 0.711 , showing its coherence about Chilean population.

\section{General Self-efficacy Scale (GSES)}

A one-dimensional self-report scale that is assessed using a Likert-type scale made of 10 items with four options ranging from one (incorrect) to four (correct). Its reliability is demonstrated by reaching a Cronbach's alpha of 0.84 . This instrument was validated for a Chilean population by Cid et al. in 2010 .

\section{Anthropometric Evaluation}

Weight was determined with a calibrated SECA ${ }^{\circledR}$ mechanical column lever of $220 \mathrm{~kg}$ scale for adults, and the height was determined with a height rod of SECA ${ }^{\circledR}$ Brand graduated in $\mathrm{mm}$. In order to calculate the BMI, the Quetelet rate was used.

\section{Statistical Analysis}

An exploratory analysis of the data was made in order to identify mistakes, missing and unusual values and to identify the distribution of the data. Those without normal distribution were turned into a logarithmic scale, and reanalyzed. Later, frequency tables were built for qualitative variables, and calculations about average and standard deviation in quantitative variables. Spearman's Rho statistic was used to determine the relationship between the quantitative variables, since the variables did not present a normal distribution, even after a logarithmic transformation.

A Kruskal Wallis test was used to find differences between variables. All the results were analyzed using the SPSS computer program version 22.0 for Windows. 


\section{RESULTS}

The results of the general descriptive analysis can be seen in Table 1.

The results according to the different classes of obesity start from medium levels in each questionnaire, the highest scores are presented in class II obesity, except for general self-efficacy. Statistically significant differences are observed according to the class of obesity in dimensions like: a) stress, b) confidence and c) ability in solving problems and unexpected situations. Class I Obesity presents differences from classes II and III. See Table 2.
There is a mild positive linear relationship between Stress and Difficulty of Emotional Regulation $(\mathrm{rho}=0.242)$, Stress and BMI $($ rho $=0.380)$. Stress and age have a moderate relationship $($ rho $=0.334)$. Difficulty of emotional regulation variable presented a negative correlation with perceived selfefficacy (rho $=-0.419$ ). Difficulty of emotional regulation presents a mild linear relationship with the body mass index $($ rho $=0.214)$. See Table 3 .

Table 1

Description of Scales and Subscales Used

\begin{tabular}{|c|c|c|c|c|c|c|}
\hline \multirow{2}{*}{$\begin{array}{l}\text { Variables } \\
\text { Body Mass Index }\end{array}$} & \multicolumn{3}{|c|}{ Mean \pm SD } & \multirow{2}{*}{$\begin{array}{c}\text { Percentile } \mathbf{2 5} \\
31\end{array}$} & \multirow{2}{*}{$\begin{array}{c}\text { Median } \\
34\end{array}$} & \multirow{2}{*}{$\begin{array}{c}\text { Percentile 75 } \\
40\end{array}$} \\
\hline & 36.44 & \pm & 6.07 & & & \\
\hline Perception scale global stress & 30.84 & \pm & 7.67 & 27 & 33 & 37 \\
\hline General self-efficacy scale & 33 & \pm & 5.12 & 31 & 35 & 37 \\
\hline Emotional regulation questionnaire & 61.13 & \pm & 18.3 & 46 & 56 & 72 \\
\hline Emotional rejection & 7.44 & \pm & 3.55 & 9 & 14 & 23 \\
\hline Daily interference & 7.16 & \pm & 2.43 & 6 & 9 & 13 \\
\hline Emotional neglect & 16.24 & \pm & 4.13 & 13 & 18 & 23 \\
\hline Emotional lack of control & 16.51 & \pm & 8.24 & 8 & 9 & 12 \\
\hline Emotional confusion & 9.59 & \pm & 4.54 & 4 & 6 & 9 \\
\hline Confidence in problem solving & 17.39 & \pm & 5.52 & 4 & 8 & 10 \\
\hline Problem solving ability & 11.15 & \pm & 5.34 & 6 & 7 & 9 \\
\hline Resolution of unexpected situations & 6.48 & \pm & 3.16 & 13 & 16 & 19 \\
\hline
\end{tabular}

Note. GSPS: Global Stress Perception Scale, GSES: General Self-Efficacy Scale, DERS-E: Difficulties in Emotion Regulation Scale . RE: Emotional rejection, CI: daily interference, DEM: emotional neglect, ED: emotional lack of control, EC: emotional confusion. CSP: confidence in problem solving; PSC: problem solving ability; RUS: resolution of unexpected situations. Data presented on average more less standard deviation, plus quartiles.

Table 2

Result Questionnaires According to Class of Obesity

\begin{tabular}{|c|c|c|c|c|}
\hline Variables & Class I & Class II & Class III & $p$ \\
\hline Global perception of stress scale & $27.2 \pm 8.3$ & $35 \pm 5.3$ & $33.5 \pm 4.7$ & 0.000 \\
\hline General self-efficacy scale & $33 \pm 4.8$ & $33 \pm 4.8$ & $32.8 \pm 18.7$ & 0.975 \\
\hline Emotional regulation questionnaire & $57 \pm 18.7$ & $66.7 \pm 19.4$ & $63.7 \pm 17.4$ & 0.083 \\
\hline Confidence in problem solving & $6 \pm 3.8$ & $8.77 \pm 3.0$ & $8.2 \pm 2.9$ & 0.039 \\
\hline Problem solving ability & $6.2 \pm 2.7$ & $8.5 \pm 2.7$ & $7.6 \pm 1.6$ & 0.003 \\
\hline Resolution of unexpected situations & $14.6 \pm 3.8$ & $17.9 \pm 3.9$ & $17.6 \pm 3.7$ & 0.002 \\
\hline Emotional rejection & $14.7 \pm 7.7$ & $19.5 \pm 7.9$ & $17.2 \pm 8.8$ & 0.079 \\
\hline Daily interference & $9 \pm 3.96$ & $10.5 \pm 5.3$ & $9.7 \pm 4.8$ & 0.756 \\
\hline Emotional neglect & $16.2 \pm 5.7$ & $18.6 \pm 5,53$ & $18.34 \pm 4.8$ & 0.178 \\
\hline Emotional confusion & $6.4 \pm 3.2$ & $6.2 \pm 3.2$ & $6.6 \pm 3.0$ & 0.834 \\
\hline Emotional lack of control & $10.5 \pm 5.3$ & $11.8 \pm 5.7$ & $11.65 \pm 5.1$ & 0.295 \\
\hline
\end{tabular}

Note. Data presented on average more or less standard deviation for each obesity class. $p<0.05$ are significant contrasts. Test used to determine differences is Kruskal Wallis, for non-normal behavior, even after taking them to logarithmic scale 
Table 3

Correlation between variables and instruments

\begin{tabular}{lccccc}
\hline Rho Spearman & EPGE & EAG & DERS-E & IMC & Age \\
\hline EPGE & 1 & 0.112 & $0.242^{*}$ & $0.380^{* *}$ & $0.334^{* *}$ \\
$p$-Value & & 0.306 & 0.025 & 0.000 & 0.002 \\
EAG & & $-0.419^{* *}$ & -0.029 & 0.171 \\
$p$-Value & 1 & 0.000 & 0.792 & 0.115 \\
DERS-E & & 1 & $0.214^{*}$ & 0.035 \\
$p$-Value & & & 0.048 & 0.749 \\
BMI & & & 1 & 0.196 \\
$p$-Value & & & & 0.071 \\
Age & & & & 1 \\
\hline
\end{tabular}

Note. GSPS: Global Stress Perception Scale, GSES: General Self-Efficacy Scale, DERS-E: Difficulties in Emotion Regulation Scale; BMI Body Mass Index. $p<0.05$ are significant contrasts.

* There is a slight linear correlation between both variables.

** There is a moderate linear correlation between both variables.

\section{DISCUSSION}

The aim of this work is to evaluate the levels of general self-efficacy, difficulty of emotional regulation and stress in obese people and how those psychological variables influence each other in order to contribute to the development of a psychological profile for the treatment and prevention of this disease. When the results were analyzed, we realized that all the scores give us results that fluctuate in the regular ranges in each of the evaluated variables, that is, obese people do not present extreme levels of stress, general selfefficacy and difficulties of emotional regulation. However, it has been observed that obesity produces negative social and psychological consequences in people (O'Brien \& Dixon, 2002; Wardle et al., 2006), constituting a mental health issue.

Nonetheless, when analyzing the results of the instruments separately according to the class of obesity, constant differences are observed between global perception of stress and difficulties of emotional regulation, providing more adaptive results for Class I obesity, followed by class III, which indicates slightly more favorable results than class II obese people, who obtain higher levels of stress and difficulty of emotional regulation, experiencing the disease in a more frustrating and stressful way (Cabello \& Zúñiga, 2007). This pattern of results is replicated in the analysis of the subscales of each instrument.

The general self-efficacy results indicate that the people in the sample maintain regular levels of self-efficacy. However, the results are below the cut-off score. As a result, we can discuss that the level of self-efficacy would not facilitate weight reduction in a possible treatment. In this sense, Lugli (2011) mentions that participating in weight loss treatments is a self-efficacy indicator, but although this leads the decision to start a treatment, it is not enough to continue it, nor to organize and take required actions to manage future situations associated with weight (Bandura, 2003). Jex et al., (2001) explain that self-efficacy can act as a buffer against stressors, once higher levels of self-efficacy lead to lower levels of psychological distress, thus the results obtained within the normal ranges in the variables evaluated in this investigation could be explained by the level of self-efficacy.

The stress scale showed to be closely related with the class of obesity (Kruskal-Wallis $p<0.05$ ), indicating differences between stress levels and types of obesity. Class I has lower stress ranges than the others, with an average of $(\mathrm{M}=27.2, \mathrm{SD}=8.3)$, and class III $(\mathrm{M}=33.5, \mathrm{SD}=4.7)$ has better results than class II $(\mathrm{M}=35, \mathrm{SD}=5.3)$ in this variable. This way, the relationship between stress and obesity is proposed, and people with more stress have more weight gain than expected per calorie consumed (Kuo et al, 2007). In this sense, people with class II obesity would be in this condition. As Behar and Valdés (2009) mention, stress is related to eating disorders, weight gain and BMI increase. In the same way as our results, studies suggest that an inadequate management of chronic stress, such as eating unhealthy or excessive food intake to compensate bad feelings, contributes to obesity (Dallman et al, 2003). The results show a positive relationship between stress and age - older people, more stress - thus it is necessary to highlight the severity of obesity in the identity of the adult.

The nutritional status of the person is influenced by the demands of the environment and its internal characteristics to cope with the situation, when exposed to a stressful one, an obese person will regulate stress level through an inadequate food intake (Behar \& Valdés, 2009; Cordella \& Moore, 2015).

Although the results in emotional regulation difficulty fluctuate within normal levels, they are presented over the cut-off score. It is relevant to emphasize the importance of this variable in obesity treatment, because it is the one that defines the behavior adopted when emotional states are confronted; positively regulated emotions is related to important psychological, social and physical health variables (Gross, 2002, 2007). Not being able to regulate them could be the basis of mood and anxiety disorders (Campbell-Sills 
et al., 2006), antecedents present in morbidly obese people (Abilés et al, 2010; Cordella \& Moore, 2015), which must be considered. By not presenting optimal levels of emotional regulation, obese people could turn to basic systems of compensation (calorie intake), because of the difficulty in distinguishing different emotions, mistaking anxiety for hunger (Goleman, 1999; Silva, 2007; Cordella, 2008).

The results indicated that the difficulty of emotional regulation is inversely related to general self-efficacy and positively related to stress. We can affirm that psychotherapeutically intervening, emphasizing the processes of self-observation over the difficulty of emotional regulation (Guidano, 1983, 1999), could improve people's self-efficacy levels, achieving better projections of treatment for weight loss (Tippens et al., 2014). In addition, it could reduce stress levels, which has a great influence on compulsive caloric intake behaviors (Cordella \& Moore, 2015). Theoretical framework connects the difficulty of emotional regulation with depression and anxiety, two variables that, even if not studied in depth during this research, have shown to be of great importance to understand obesity from the psychological perspective and its treatments
(Calderón et al., 2010; Cofré-Lizama et al., 2017; Cofré et al., 2014; Delgado, et al, 2015), which makes this variable very important in order to understand the processes of emotional regulation of an obese person.

Our research suggests that there is a psychological curve behind the fattening process in which class I and II obese people get better results than those in class II. Although the levels of the evaluated variables (General Self-efficacy, Difficulty in Emotional Regulation and Perceived Stress) are not pathological in this sample, they are related to the level of obesity, indicators that would allow to plan better psychological and multidisciplinary treatment.

Although we consider this research has been a start for a deeper understanding of the process associated to obesity, more research is needed to corroborate these results in order to create definitive information and improve this issue and to design an effective and a long lasting treatment to defeat obesity, a pandemic disease that instead of stopping is still increasing. This represents an important expense for health systems for its close relationship with chronic non-transmissible diseases and a significant deterioration of obese people's life quality.

\section{REFERENCES}

Abilés, V., Rodríguez-Ruiz, S., Abilés, J., Mellado, C., García, A., Pérez de la Cruz, A. \& Fernández-Santaella, M. C. (2010). Psychological Characteristics of Morbidly Obese Candidates for Bariatric Surgery. Obesity Surgery, 20(2), 161-167. http:// doi.org/10.1007/s11695-008-9726-1

Bandura, A., Caprara, G., Barbaranelli, C., Gerbino, M. \& Pastorelli, C. (2003). Role of Affective Self-Regulatory Efficacy in Diverse Spheres of Psychosocial Functioning. Child Development, 74(3), 769-782. https://doi.org/10.1111/1467-8624.00567

Behar A., \& Valdés C., (2009) Estrés y Trastornos de la Conducta Alimentaria [Stress and Eating Disorders]. Revista Chilena de Neuro-Psiquiatía 14(3), 178-189. http://dx.doi.org/10.4067/ S0717-92272009000300002

Cabello, G. M., \& Zúñiga, Z.J. (2007). Aspectos Intrapersonales y Familiares Asociados a la Obesidad: un Análisis Fenomenológico [Intrapersonal and Family Aspects Associated with Obesity: a Phenomenological Analysis]. Ciencia UANL, 10(2), 183-188.

Calderón, C., Forns, M., \& Vera, V. (2010). Implicación de la Ansiedad y la Depresión en los Trastornos de Alimentación de Jóvenes con Obesidad. Nutrición Hospitalaria, 25(4), 641-647.

Campbell-Sills, L., Barlow, D. H., Brown, T. A., \& Hofmann, S. G. (2006). Effects of Suppression and Acceptance on Emotional Responses of Individuals with Anxiety and Mood Disorders. Behaviour Research and Therapy, 44, 1251-1263. https://doi. org/10.1016/j.brat.2005.10.001

Cid, P., Orellana, Y., \& Barriga, O. (2010). Validación de la Escala de Autoeficacia General en Chile [General Self-Efficacy Scale Validation in Chile]. Revista Médica de Chile, 138(5), 551-557. http://dx.doi.org/10.4067/S0034-98872010000500004

Cofré, A., Angulo, P., \& Riquelme, E. (2014) Ansiedad y Depresión en Pacientes Obesos Mórbidos: Efectos a Corto Plazo de un Programa Orientado a la Disminución de la Sintomatología [Anxiety and Depression in Morbid Obesity Patients: Short-Term Effect of a Program Oriented to the Diminution of the Symptomatology]. Summa psicológica UST (en línea), 11(1), 89-98.

Cofré-Lizama, A., Delgado-Floody, P., Saldivia-Mansilla, C., \& Jerez-Mayorga, D. (2017). Diagnóstico Integral en Pacientes Obesos Mórbidos Candidatos a Cirugía Bariátrica y Sugerencias para su Tratamiento Preoperatorio [Comprehensive Diagnosis in Patients with Morbid Obesity; Candidates for Bariatric Surgery and Suggestions for Preoperative Treatment]. Revista de Salud Pública, 19(4), 527-532. https://doi.org/10.15446/ rsap.v19n4.50809

Company, R., Orbest, U., \& Sánchez, F. (2012). Regulación Emocional Interpersonal de las Emociones de Ira y Tristeza [Interpersonal Emotional Regulation of Anger and Sadness]. Boletín de Psicología, 104, 7-36.

Cordella, P. (2008). ¿Incluir la obesidad en el manual de enfermedades mentales (DSM-IV)? Revista Chilena de Nutrición, 35(3), 181187. http://dx.doi.org/10.4067/S0717-75182008000300003

Cordella, P., \& Moore, C. (2015). Patrón Adaptativo Obesogénico Cerebral: Una Propuesta para Comprender y Evaluar la Obesidad en la Práctica Clínica. Revista Chilena de Nutrición, 42(1), 60-69. http://dx.doi.org/10.4067/S071775182015000100008

Dallman, M., Pecoraro, N., Akana, S., la Fleur, S., Gómez, F., Houshvar, H., Bell, M., Bhatnagar, S., Laugero, K., \& Manalo, S. (2003). Chronic Stress and Obesity: A New View of "Comfort Food". Proceedings of the National Academy of Sciences, 100(20), 11696-11701. https://doi.org/10.1073/ pnas. 1934666100

de la Iglesia, R., Lopez-Legarrea, P., Abete, I., Bondia-Pons, I., NavasCarretero, S., Forga, L., Martínez, J., \& Zulet, M. (2014) A New Dietary Strategy for Long-Term Treatment of the Metabolic Syndrome is Compared with the American Heart Association (AHA) Guidelines: 12 the MEtabolic Syndrome REduction in NAvarra (RESMENA) Project. The British Journal of Nutrition, 111(4),643-52. https://doi.org/10.1017/S0007114513002778

Delgado, P., Cofré, A., Alarcón, M., Osorio, A., Caamaño, F., \& Jerez D. (2015). Evaluación de un Programa Integral de Cuatro Meses de Duración sobre las Condiciones Preoperatorias de Pacientes Obesos Candidatos a Cirugía Bariátrica [Evaluation of a Comprehensive Program of Four Months of Duration on the Preoperative Conditions of Obese Patients Candidates for Bariatric Surgery]. Nutrición Hospitalaria, 32(03), 1022-7. http://dx.doi.org/10.3305\%2Fnh.2015.32.3.9350 
Durán, M. (2009). Bienestar Psicológico: El Estrés y la Calidad de Vida en el Trabajo [Psychological Well-Being: Stress and Quality of Life at Work]. Revista Nacional de Administración, 1(1), 71-84. https://doi.org/10.22458/rna.vli1.285

Elder, C., Guillion, K., Funk, K., BeBar, L., Lindberg, N., \& Stevens, V. (2011). Impact of Sleep, Screen Time, Depression and Stress on Weight Change in the Intensive Weight Loss Phase of the Life Study. International Journal of Obesity. 36(1), 86-92. https://doi.org/10.1038/ijo.2011.60

García-Rivera, B., Maldonado-Radillo, S. \& Ramirez M. (2013). Estados Afectivos Emocionales (Depresión, Ansiedad, Estrés) en Personal de Enfermería del Sector Salud Pública de México [Emotional Affective States (Depression, Anxiety and Stress) of Nursing in a Mexican Public Health Sector]. SUMMA psicológica UST, 11(1) 65-73.

Goleman, D. (1999). Inteligencia emocional. Kairós.

González, L., Giraldo, N., Estrada, A., Muñoz, A., Mesa, E. \& Herrera, C. (2007). La Adherencia al Tratamiento Nutricional y Composición Corporal: Un Estudio Transversal en Pacientes con Obesidad o Sobrepeso [Adherence to the Nutritional Treatment and the Body Composition: A Study Cross-Sectional in Patients with Obesity or Overweight]. Revista chilena de nutrición, 34, (1), 46-54.

Groesz, L., McCoy, S., Carl, J., Saslow, L., Stewart, J., Adler, N., Laraia, B., \& Epel, E. (2011). What is Eating You? Stress and the Drive to Eat. Appetite, 58(2), 717-21. https://doi. org/10.1016/j.appet.2011.11.028

Gross, J. J. (2002) Emotion Regulation: Affective, Cognitive, and Social Consequences. Psychophysiology, 39, 281-91. http:// doi.org/10.1017/S0048577201393198

Gross J. J. (2007). The Handbook of Emotion Regulation. Guilford Press.

Guidano, V. F., \&Liotti, G. (1983). Cognitive processes and emotional disorders. Guilford.

Guidano, V. F. (1999). Psicoterapia: Aspectos Metodologicos, Cuestiones Clinicas y Problemas Abiertos desde una Perspectiva Post-Racionalista [Psychotherapy: Methodological Aspects, Clinical Issues and Open Problems from a PostRationalist Perspective]. Revista Psicoterapia, 37, 95-105.

Guzmán-González, M., Trabucco, C., Urzúa, A., Garrido, L., \& Leiva, J. (2014). Validez y Confiabilidad de la Versión Adaptada al Español de la Escala de Dificultades de Regulación Emocional (DERS-E) en Población Chilena [Validity and Reliability of the Adapted Spanish Version of the Difficulties in Emotion Regulation Scale in Chilean Population]. Terapia psicológica, 32(1), 46-54. http://dx.doi.org/10.4067/S0718-48082014000100002

Hayden, J. \& Peterson, W. (2014). Introduction to Health Behavior Theory $\left(2^{\text {nd }} E d.\right)$. Jones \& Bartlett Learning.

Hernández, Z., \& Ehrenzeweig , Y. (2009). Factores Psicológicos, Demográficos y Sociales Asociados al Estrés y a la Personalidad Resistente en Adultos Mayores [Psychological, Demographic and Social Factors Associated with Stress and Resistant Personality in Older Adults]. Pensamiento Psicológico, 5(12), 13-28

Jex, S., Bliese, P., Buzzell, S., \& Primeau, J. (2001). The Impact of Self-Efficacy on Stressor-Strain Relations: Coping Style as an Exploratory Mechanism. Journal of Applied Psychology, $86,401-409$

Karamouzis, I., Pervanidou, P., Berardelli, R.,Iliadis, S., Papassotiriou, I., Karamouzis, M., Chrousos, G. P., \& KanakaGantenbein, C. (2011). Enhanced Oxidative Stress and Platelet Activation Combined with Reduced Antioxidant Capacity in Obese Prepubertal and Adolescent Girls with Full or Partial Metabolic Syndrome. Hormone and Metabolic Research, 43(9), 607-613. https://doi.org/10.1055/s-0031-1284355

Kuo, L. E., Kitlinska, J. B., Tilan, J. U., Li, L., Baker, S. B., Johnson, M. D., Lee, E. W., Burnett, M. S., Fricke, S. T., Kvetnansky, R., Herzog, H., \& Zukowska, Z. (2007). Neuropeptide y Acts Directly in the Periphery on Fat Tissue and Mediates StressInduced Obesity and Metabolic Syndrome. Nature Medicine, 13, 803-811. https://doi.org/10.1038/nm1611
Kushner, R. F. (2014) Weight Loss Strategies for Treatment of Obesity. Progess in Cardiovascular Dissease,56(4): 465-72. https://doi.org/10.1016/j.pcad.2013.09.005

Limonero, J., Tomás, J., Fernández, J., Gómez, M., \& Ardilla, A., (2012). Estrategias de Afrontamiento Resilientes y Regulación Emocional: Predictores de Satisfacción con la Vida [Resilient Coping Strategies and Emotional Regulation: Predictors of Life Satisfaction]. Behavioral Psychology/Psicología Conductual, 20 (1), 183-196.

Lorence, B. (2008). Perfil Psicológico de la Obesidad Mórbida [Psychological Profile of Morbid Obesity]. Apuntes de Psicología, 26(1), 51-68.

Lugli, Z. (2011). Autoeficacia y Locus de Control: Variables Predictoras de la Autorregulación del Peso en Personas Obesas [Self-efficacy and Locus of Control: Predictive Variables of Self-regulation of Weight in Obese People]. Pensamiento Psicológico, 9(17), 43-55.

MINSAL. (2010). Indicadores de la Obesidad en Población Chilena. Retrieved from http://web.minsal.cl/portal/url/item /9ad9cbfb71ca4705e04001011e010283.pdf

MINSAL. (2013). Panorama de Salud 2013. Informe OECD sobre Chile y comparación con países miembros. Retrieved from http://web.minsal.cl/sites/default/files/INFORME\%20 OCDE 2013 21\%2011 final.pdf

Olivarí, C., \& Urra, E. (2007). Autoeficacia y Conductas de Salud [Self-Efficacy and Health Behaviors]. Ciencia y Enfermería, 13(1), 9-15. http://dx.doi.org/10.4067/S071795532007000100002

Sánchez, C., Ibáñez, C., \& Klaassen, J. (2014). Obesidad y Cáncer: la Tormenta Perfecta [The Link between Obesity and Cancer]. Revista Médica de Chile, 142(2), 211-221. http://dx.doi. org/10.4067/S0034-98872014000200010

Silva, J. R. (2007). Sobrealimentación Inducida por la Ansiedad, Parte I: Evidencia Conductual, Afectiva, Metabólica y Endocrina [Anxiety Induced Overeating. Part I: Behavioral, Affective, Metabolic and Endocrine Evidence.]. Terapia Psicológica, 25, 112-134. http://dx.doi.org/10.4067/S071848082007000200005

Silva J. (2008). Sobrealimentación Inducida por la Ansiedad, Parte II: Un Marco de Referencia Neurocientífico para el Desarrollo de Técnicas Psicoterapéuticas y Programas de Prevención [Anxiety Induced Overeating, Part II: A Reference Framework for the Development of Psychotherapeutic Techniques and Prevention Programs]. Terapia Psicológica, 26(1), 99-115. http://dx.doi.org/10.4067/S0718-48082008000100009

Souto, A., (2013) Regulación Emocional y Estrés Académico en Estudiantes de Fisioterapia [Doctoral Dissertation, Universidade da Coruña]. Repository of Universidade da Coruña. http://ruc.udc.es/dspace/bitstream/handle/2183/11719/ SoutoGestal_AntonioJose_TD_2013.pdf? sequence $=4$

Tapia, D., Cruz, $\bar{C}$., Gallardo, I., \& Dasso, M. (2007). Adaptación de la Escala de Percepción Global de Estrés (EPGE) en Estudiantes Adultos de Escasos Recursos en Santiago, Chile [Adaptation of the Global Percieved Stress Scale in Adult Students of Low Economic Condition in Santiago, Chile]. Psiquiatría y Salud Mental, 24(1), 109-119

Tippens, K., Purnell, J., Erin, G., Hanes, D., Oken, B., \& Calabrese, C. (2014). Expectancy, Self-Efficacy, and Placebo Effect of a Sham Supplement for Weight Loss in Obese Adults. Journal of Evidence-Based Complementary \& Alternative Medicine, 19(3), 205-210. https://doi.org/10.1177/2156587214528513

Villaseñor, S., Onnteveros. C., \& Cárdenas, K. (2006) Salud Mental y Obesidad [Mental Health and Obesity]. Investigación en Salud,7(2), 86-90.

Wardle, J., Williamson, S., Johnson, F., \& Edwards, C. (2006). Depression in Adolescent Obesity: Cultural Moderators of the Depressive Symptoms. International Journal of Obesity, 30 (4), 634-643. https://doi.org/10.1038/sj.ijo.0803142

WHO (2018). Obesity and Overweight. Retrieved from https://www. who.int/news-room/fact-sheets/detail/obesity-and-overweight 